\title{
Expression Patterns of Major Genes in Fatty Acid Synthesis, Inflammation and Oxidative Stress Related Pathways and Quality Parameters During the Transition From Colostrum to Milk in Dairy
} Goats

\section{Akın YAKAN}

Department of Genetics, Faculty of Veterinary Medicine, Hatay Mustafa Kemal University, Hatay

Huseyin OZKAN ( $\nabla$ hozkan@mku.edu.tr)

Department of Genetics, Faculty of Veterinary Medicine, Hatay Mustafa Kemal University, Hatay

\section{Baran ÇAMDEVIREN}

Department of Biochemistry and Genetics, Institute of Health Sciences, Hatay Mustafa Kemal University, Hatay

\section{Ufuk KAYA}

Department of Biostatistics, Faculty of Veterinary Medicine, Hatay Mustafa Kemal University, Hatay İrem KARAASLAN

Technology and Research \& Development Center (MARGEM), Hatay Mustafa Kemal University, Hatay

\section{Sevda DALKIRAN}

Department of Biochemistry and Genetics, Institute of Health Sciences, Hatay Mustafa Kemal University, Hatay

\section{Research Article}

Keywords: Goat colostrum, transition milk, somatic cell gene expression, milk fatty acid profile

Posted Date: December 28th, 2020

DOl: https://doi.org/10.21203/rs.3.rs-129719/v1

License: (c) (1) This work is licensed under a Creative Commons Attribution 4.0 International License. Read Full License 


\section{Abstract}

Colostrum is quietly different from mature milk. The molecular regulation of milk secretion and quality in the transition period from colostrum to milk in goats is largely unknown. The present study, mammary gland secretion of goats was collected in $0^{\text {th }}, 4^{\text {th }}, 7^{\text {th }}, 14^{\text {th }}$ and $28^{\text {th }}$ days after parturition. In addition to composition and fatty acid profile of colostrum or milk, FASN, SCD, ACACA, COX-2, NRF2, TLR2, NF-kB, $L T F$ and $P T X 3$ genes expression patterns were determined from milk somatic cells. While somatic cell count (SCC), malondialdehyde (MDA), fat, fat-free dry matter (FFDM), protein and lactose were highest as expression levels of the oxidative and inflammatory genes $(P<0.05)$, freezing point and electrical conductivity were lowest in colostrum. With the continuation of lactation, most of the fatty acids, n3 ratio, and odour index had increased, on the other hand, C14:0 and C16:0 had decreased. In addition, FASN was upregulated almost 3 folds in $14^{\text {th }}$ day $(P<0.05)$. While $S C D$ was similar, $A C A C A$ was upregulated more than 5 folds in $7^{\text {th }}$ and $14^{\text {th }}$ days $(P<0.05)$. Furthermore, significant correlations were determined between studied genes. Although colostrum is important for offspring health in terms of inflammation and oxidative stress related pathways, further studies are needed on complex molecular pathways including fatty acid synthesis on goat mammary gland.

\section{Introduction}

The world human population is expected to be around 10 billion by 2050 . Animal production targets are rising in response to the increasing world population. Goat is an important farm animal for the production of dairy products, as well as for the supply of healthy, high-quality and valuable food, especially for the nutrition of children, the elderly and those with food allergies ${ }^{1,2}$. With the increasing demand for goat milk in recent years, goat breeding has gained importance and the amount of milk production has increased with the number of goats ${ }^{3,4}$.

Milk, an important animal product, is a vital biological secretion that begins with the birth. First secretion of mammary tissue, colostrum, has quietly different from mature milk. Besides its immunological function, colostrum is pivotal for the initial intake of nutrients in terms of the survival and sustainable health of the newborn ${ }^{5}$. Regulation of mammary secretion is controlled by local and systemic factors. Therefore, colostrum and milk components are regulated by different mechanisms ${ }^{5}$.

Goat colostrum is richer in somatic cells, fat, protein, FFDM, lactose and immunoglobulins ${ }^{5,6}$. The considered changes occur in composition and properties during the transition from colostrum to mature milk. It has been reported that goat colostrum turns into milk in $4-5$ days after birth goats ${ }^{6,7}$. On the other hand, transition to mature milk secretion is a process rather than straight conversion.

As is well known, milk traits are affected by genetic and environmental factors such as breed type, age, and parity. In addition, unlike other farm animals the milk secretion type of goats is apocrine ${ }^{1}$. Several studies have deepened to improve the molecular basis of milk secretion in cattle, however what is known 
about the molecular basis in the regulation of milk secretion and quality particularly in the transition period from colostrum to milk in goats is limited ${ }^{8,9}$.

The aims of this study were as follows:

1. Determination of the changes in macromolecules (fat, protein, lactose etc.) and some milk parameters $(\mathrm{pH}$, electrical conductivity, freezing point, FFDM etc.) of mammary secretion from parturition to 28 th day in goats.

2. Investigation of fatty acid profile of the mammary secretion during colostrum to mature milk in Damascus goats.

3. Expression analysis of the genes related with fatty acid profile, inflammation and oxidative stress related pathways in milk somatic cells of goats.

4. Reveal the correlations between the mentioned genes in milk somatic cells of goats.

For the purposes of the study, milking samples were collected from the goats after parturition ( 5 times from 0th to 28th day). In addition to composition and fatty acid profile determination of mammary secretion, expression levels of FASN (Fatty Acid Synthase), SCD (Sterol CoA Desaturase), ACACA (AcetylCoA Carboxylase Alpha), COX-2 (Cyclooxygenase 2), NRF2 (Nuclear factor erythroid 2-related factor 2), TLR2 (Toll-like Receptor 2), NF-kB (Nuclear Factor Kappa-light-chain-enhancer of Activated B Cells), LTF (Lactoferrin) and, PTX3 (Pentraxin 3) genes were determined from milk somatic cells.

\section{Results}

The properties of colostrum or milk obtained have presented in Figure 1. The SCC was around 5 million on the $0^{\text {th }}$ day, then it decreased dramatically on the $4^{\text {th }}$ day and was around 1 million by the $7^{\text {th }}$ day. Following the lactation, the SCC was around $400 \times 10^{3} / \mathrm{mL}$ in milk $(\mathrm{P}<0.01)$. While $\mathrm{pH}$ value was increased day by day, the levels of fat (\%), FFDM (\%), protein (\%), and lactose (\%) were decreased with the varying levels of significance $(P<0.001)$. On the other hand, the freezing point and electrical conductivity of the samples increased on the $4^{\text {th }}$ day and remained at similar levels on the following days $(P<0.001)$. The level of MDA was highest with the $34.41 \pm 2.43 \mathrm{nmol} / \mathrm{mL}$ values in the $0^{\text {th }}$ day $(P<0.001)$. However, it was 3 times lower on the following days and there were no significant differences between these days.

The proportions of short and medium-chain fatty acids had significantly changed with the continuation of lactation. While C4:0, C6:0, C8:0, C10:0, C15:1 fatty acids were lowest levels, they had gradually increased $(P<0.001)$. Moreover, a fluctuating change was observed in C12:0, C16:1, C17:0, C17:1, C18:2 trans, C18:2 cis fatty acid levels. On the other hand, C14:0 and C16:0 fatty acids decreased towards to $28^{\text {th }}$ day. Moreover, C18:3 n3, C20:1, C20:2 n6, and C20:0 increased in 28 ${ }^{\text {th }}$ day, and C20:4 n6 was higher in $0^{\text {th }}$ day than the other days. Saturated fatty acids (SFA), monounsaturated fatty acids (MUFA) and unsaturated fatty acids (UFA) were similar in all sampled days. Furthermore, significant changes were determined in terms of polyunsaturated fatty acids (PUFA) of mammary secretion $(P<0.001)$. The $n 6$ and 
n3 fatty acid levels of samples were highest on $28^{\text {th }}$ day $\left(P<0.01 ; P<0.001\right.$, respectively). However, on $28^{\text {th }}$ day, $n 6 / n 3$ ratio was significantly lower than those of other days $(P<0.01)$. Except for $0^{\text {th }}$ day, odour index was similar on all days. The lowest odour index was found on $0^{\text {th }}$ day $(P<0.001)$. In addition to nutritional value, atherogenic and thrombogenic indexes values were similar (Table 1).

Table 1. Fatty acids profile of milk samples in different stages of lactation; $*: P<0.05 ; * \star$ : $P<0.01 ; * \star *$ : P<0.001; NS: Not significant; Ol: Odour index NV: Nutritional value; Al: Atherogenic index; Tl: Thrombogenic index 


\begin{tabular}{|c|c|c|c|c|c|c|}
\hline Parameters & $0^{\text {th }}$ day & $4^{\text {th }}$ day & $7^{\text {th }}$ day & $14^{\text {th }}$ day & $28^{\text {th }}$ day & $\mathbf{P}$ \\
\hline C4:0 & $0.25 \pm 0.03^{d}$ & $0.74 \pm 0.07^{c}$ & $1.14 \pm 0.09^{\mathrm{ab}}$ & $0.92 \pm 0.13^{b c}$ & $1.50 \pm 0.11^{\mathrm{a}}$ & 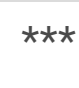 \\
\hline C6:0 & $0.59 \pm 0.09^{c}$ & $1.38 \pm 0.10^{b}$ & $1.90 \pm 0.11^{\mathrm{a}}$ & $1.73 \pm 0.16^{\mathrm{ab}}$ & $1.92 \pm 0.14^{\mathrm{a}}$ & $\star * *$ \\
\hline C8:0 & $0.83 \pm 0.14^{b}$ & $1.78 \pm 0.14^{\mathrm{a}}$ & $2.12 \pm 0.17^{a}$ & $2.21 \pm 0.19^{a}$ & $2.08 \pm 0.21^{\mathrm{a}}$ & 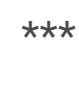 \\
\hline C10:0 & $2.95 \pm 0.43^{b}$ & $5.47 \pm 0.4^{a}$ & $6.16 \pm 0.41^{a}$ & $6.42 \pm 0.52^{\mathrm{a}}$ & $5.87 \pm 0.64^{\mathrm{a}}$ & 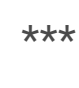 \\
\hline C12:0 & $1.79 \pm 0.16^{b}$ & $\begin{array}{l}2.47 \pm \\
0.18^{\mathrm{ab}}\end{array}$ & $2.60 \pm 0.18^{a}$ & $2.50 \pm 0.18^{a b}$ & $\begin{array}{l}2.19 \pm \\
0.20^{\mathrm{ab}}\end{array}$ & * \\
\hline C14:0 & $8.70 \pm 0.54^{\mathrm{a}}$ & $\begin{array}{l}7.58 \pm \\
0.40^{\mathrm{ab}}\end{array}$ & $7.34 \pm 0.38^{\mathrm{ab}}$ & $7.13 \pm 0.46^{\mathrm{ab}}$ & $6.42 \pm 0.41^{b}$ & * \\
\hline C14:1 & $0.08 \pm 0.01$ & $0.08 \pm 0.01$ & $0.07 \pm 0.01$ & $0.06 \pm 0.01$ & $0.06 \pm 0.01$ & NS \\
\hline C15:0 & $0.49 \pm 0.02$ & $0.49 \pm 0.02$ & $0.47 \pm 0.03$ & $0.46 \pm 0.02$ & $0.46 \pm 0.02$ & NS \\
\hline C15:1 & $0.20 \pm 0.01^{b}$ & $0.18 \pm 0.0^{b}$ & $0.20 \pm 0.01^{b}$ & $0.22 \pm 0.02^{b}$ & $0.28 \pm 0.01^{\mathrm{a}}$ & $* \star *$ \\
\hline C16:0 & $\begin{array}{l}29.14 \pm \\
0.97^{a}\end{array}$ & $\begin{array}{l}26.01 \pm \\
0.59^{\mathrm{b}}\end{array}$ & $\begin{array}{l}24.56 \pm \\
0.56^{b c}\end{array}$ & $\begin{array}{l}24.41 \pm \\
0.63^{b c}\end{array}$ & $\begin{array}{l}22.89 \pm \\
0.70^{c}\end{array}$ & $\star \star \star *$ \\
\hline C16:1 & $1.17 \pm 0.03^{a}$ & $0.98 \pm 0.04^{b}$ & $0.79 \pm 0.07^{c}$ & $0.83 \pm 0.05^{b c}$ & $\begin{array}{l}1.00 \pm \\
0.02^{\mathrm{ab}}\end{array}$ & $\star \star \star *$ \\
\hline C17:0 & $\begin{array}{l}1.12 \pm \\
0.05^{\mathrm{ab}}\end{array}$ & $0.97 \pm 0.05^{b}$ & $0.98 \pm 0.04^{b}$ & $0.99 \pm 0.06^{\mathrm{ab}}$ & $1.31 \pm 0.17^{a}$ & * \\
\hline C17:1 & $\begin{array}{l}0.55 \pm \\
0.04^{\mathrm{ab}}\end{array}$ & $0.52 \pm 0.05^{b}$ & $0.63 \pm 0.06^{a b}$ & $0.58 \pm 0.05^{\mathrm{ab}}$ & $0.78 \pm 0.09^{a}$ & * \\
\hline C18:0 & $19.29 \pm 0.94$ & $19.38 \pm 1.18$ & $20.08 \pm 1.41$ & $21.41 \pm 1.52$ & $18.61 \pm 0.89$ & NS \\
\hline C18:1 & $23.08 \pm 0.76$ & $22.83 \pm 0.94$ & $21.41 \pm 0.92$ & $20.41 \pm 1.00$ & $20.43 \pm 0.85$ & NS \\
\hline C18:2 trans & $\begin{array}{l}0.88 \pm \\
0.12^{\mathrm{ab}}\end{array}$ & $0.66 \pm 0.08^{b}$ & $0.57 \pm 0.06^{b}$ & $0.69 \pm 0.08^{\mathrm{ab}}$ & $1.08 \pm 0.19^{\mathrm{a}}$ & * \\
\hline C18:2 cis & $\begin{array}{l}4.21 \pm \\
0.22^{\mathrm{ab}}\end{array}$ & $3.85 \pm 0.27^{b}$ & $4.69 \pm 0.17^{a b}$ & $4.46 \pm 0.26^{a b}$ & $5.30 \pm 0.48^{a}$ & * \\
\hline C20:0 & $0.38 \pm 0.04^{b}$ & $0.32 \pm 0.03^{b}$ & $0.41 \pm 0.04^{b}$ & $0.40 \pm 0.04^{b}$ & $0.62 \pm 0.07^{\mathrm{a}}$ & $\star \star \star *$ \\
\hline C18:3 n6 & $0.52 \pm 0.05$ & $0.52 \pm 0.06$ & $0.50 \pm 0.04$ & $0.47 \pm 0.05$ & $0.57 \pm 0.06$ & NS \\
\hline C18:3 n3 & $0.95 \pm 0.18^{b}$ & $1.13 \pm 0.19^{b}$ & $1.21 \pm 0.12^{b}$ & $0.97 \pm 0.09^{b}$ & $2.61 \pm 0.48^{a}$ & $\star * *$ \\
\hline C20:1 & $0.65 \pm 0.09^{b}$ & $0.49 \pm 0.06^{b}$ & $0.56 \pm 0.07^{b}$ & $0.61 \pm 0.06^{b}$ & $1.12 \pm 0.20^{\mathrm{a}}$ & $* * *$ \\
\hline C20:2 n6 & $0.33 \pm 0.06^{b}$ & $0.27 \pm 0.03^{b}$ & $0.28 \pm 0.03^{b}$ & $0.43 \pm 0.06^{b}$ & $0.76 \pm 0.13^{a}$ & $* \star *$ \\
\hline
\end{tabular}




\begin{tabular}{|c|c|c|c|c|c|c|}
\hline C22:0 & $0.11 \pm 0.02$ & $0.12 \pm 0.02$ & $0.10 \pm 0.01$ & $0.12 \pm 0.02$ & $0.16 \pm 0.03$ & NS \\
\hline C20:3 n3 & $0.13 \pm 0.02$ & $0.11 \pm 0.03$ & $0.07 \pm 0.01$ & $0.09 \pm 0.01$ & $0.12 \pm 0.02$ & NS \\
\hline C20:4 n6 & $0.51 \pm 0.04^{\mathrm{a}}$ & $0.32 \pm 0.02^{b}$ & $0.26 \pm 0.02^{b}$ & $0.22 \pm 0.02^{b}$ & $0.27 \pm 0.04^{b}$ & $\star \star \star$ \\
\hline $\mathrm{C} 22: 2 \mathrm{n} 6$ & $0.09 \pm 0.01$ & $0.10 \pm 0.01$ & $0.07 \pm 0.01$ & $0.09 \pm 0.01$ & $0.08 \pm 0.01$ & NS \\
\hline C20:5 n3 & $0.10 \pm 0.01$ & $0.09 \pm 0.01$ & $0.07 \pm 0.01$ & $0.08 \pm 0.01$ & $0.08 \pm 0.01$ & NS \\
\hline C24:1 & $0.88 \pm 0.13$ & $1.12 \pm 0.32$ & $0.72 \pm 0.11$ & $1.05 \pm 0.20$ & $1.40 \pm 0.29$ & NS \\
\hline C22:6 n3 & $0.03 \pm 0.005$ & $0.04 \pm 0.003$ & $0.03 \pm 0.002$ & $0.03 \pm 0.003$ & $0.04 \pm 0.004$ & NS \\
\hline SFA & $65.64 \pm 1.25$ & $66.72 \pm 1.30$ & $67.87 \pm 1.20$ & $68.71 \pm 1.24$ & $64.00 \pm 1.51$ & NS \\
\hline MUFA & $26.60 \pm 0.85$ & $26.19 \pm 1.06$ & $24.38 \pm 1.01$ & $23.76 \pm 1.11$ & $25.08 \pm 0.95$ & NS \\
\hline PUFA & $7.76 \pm 0.53^{b}$ & $7.09 \pm 0.35^{b}$ & $7.75 \pm 0.34^{b}$ & $7.53 \pm 0.39^{b}$ & $\begin{array}{l}10.92 \pm \\
1.20^{\mathrm{a}}\end{array}$ & $\star \star \star *$ \\
\hline UFA & $34.36 \pm 1.25$ & $33.28 \pm 1.30$ & $32.13 \pm 1.20$ & $31.29 \pm 1.24$ & $36.00 \pm 1.51$ & NS \\
\hline n6 & $\begin{array}{l}6.68 \pm \\
0.40^{\mathrm{ab}}\end{array}$ & $5.84 \pm 0.32^{b}$ & $6.44 \pm 0.24^{\mathrm{ab}}$ & $6.44 \pm 0.35^{\mathrm{ab}}$ & $8.19 \pm 0.79^{a}$ & $\star \star \star$ \\
\hline n3 & $1.21 \pm 0.20^{b}$ & $1.36 \pm 0.20^{b}$ & $1.37 \pm 0.13^{b}$ & $1.17 \pm 0.09^{b}$ & $2.86 \pm 0.50^{\mathrm{a}}$ & $\star \star \star *$ \\
\hline n6/n3 & $7.46 \pm 0.8^{a}$ & $6.01 \pm 0.68^{a}$ & $5.51 \pm 0.52^{\mathrm{ab}}$ & $6.23 \pm 0.66^{\mathrm{a}}$ & $3.61 \pm 0.38^{b}$ & $* * \star$ \\
\hline OI & $4.63 \pm 0.67^{b}$ & $9.38 \pm 0.69^{a}$ & $11.33 \pm 0.68^{a}$ & $11.28 \pm 0.92^{\mathrm{a}}$ & $\begin{array}{l}11.32 \pm \\
1.00^{\mathrm{a}}\end{array}$ & $\star \star *$ \\
\hline NV & $1.49 \pm 0.06$ & $1.65 \pm 0.07$ & $1.71 \pm 0.07$ & $1.74 \pm 0.08$ & $1.73 \pm 0.08$ & NS \\
\hline Al & $1.71 \pm 0.13$ & $1.66 \pm 0.11$ & $1.70 \pm 0.12$ & $1.75 \pm 0.12$ & $1.35 \pm 0.09$ & NS \\
\hline TI & $1.50 \pm 0.09$ & $1.45 \pm 0.08$ & $1.50 \pm 0.09$ & $1.55 \pm 0.09$ & $1.27 \pm 0.07$ & NS \\
\hline
\end{tabular}

Expression patterns of the genes associated with fatty acid synthesis and secretion showed variable regulation. Compared to $0^{\text {th }}$ day, $F A S N$ was upregulated almost 3 folds in $14^{\text {th }}$ day $(P<0.05)$. While $S C D$ was similar, $A C A C A$ was upregulated more than 5 folds in $7^{\text {th }}$ and $14^{\text {th }}$ days $(P<0.05)$, (Figure 2$)$.

The marked downregulation was determined at oxidative stress and inflammation related genes. COX-2 was downregulated more than 2 folds in $4^{\text {th }}$ and $7^{\text {th }}$ days $(\mathrm{P}<0.05)$. On the other hand, NRF2 and TLR2 were approximately 3 folds downregulated in all days with the different significances $(P<0.05$ and $\mathrm{P}<0.01)$. Therewithal, $N F-k B$ was downregulated on all days, while $P T X 3$ was downregulated close to 4 folds in $14^{\text {th }}$ and $28^{\text {th }}$ days $(P<0.05)$ (Figure 3$)$. 
The positive correlations were found between FASN and $S C D(\mathrm{r}=0.589 ; \mathrm{P}<0.0001)$ and $A C A C A(0.365$; $\mathrm{P}<0.01)$. $S C D$ and $A C A C A$ were also positively correlated $(\mathrm{r}=0.249 ; \mathrm{P}<0.05)$. While $F A S N$ had variable correlations with TLR2 $(\mathrm{r}=-0.221 ; \mathrm{P}<0.05) ; \operatorname{LTF}(\mathrm{r}=0.393 ; \mathrm{P}<0.001)$, and PTX3 $(\mathrm{r}=-0.275 ; \mathrm{P}<0.05)$, positive correlation was found between $S C D$ and $L T F(r=0.485 ; \mathrm{P}<0.001)$. Furthermore, $A C A C A$ and $L T F$ were positively correlated $(r=0.280 ; P<0.05)$.

COX-2 had positive correlations with TLR2 ( $r=0.359 ; \mathrm{P}<0.01), N F-k B(\mathrm{r}=0.517 ; \mathrm{P}<0.001)$, and NRF2 ( $r=0.479 ; P<0.001)$. In addition, positive correlations were found between TLR2 and PTX3 (0.405; $\mathrm{P}<0.001), N F-k B(\mathrm{r}=0.713 ; \mathrm{P}<0.001)$, and NRF2 $(\mathrm{r}=0.584 ; \mathrm{P}<0.001)$. Similarly, NF-kB was correlated with $P T X 3(r=0.372 ; \mathrm{P}<0.01)$ and NRF2 $(\mathrm{r}=0.611 ; \mathrm{P}<0.001)$ positively.

SCC was negatively correlated with FASN ( $\mathrm{r}=-0.407 ; \mathrm{P}<0.001), S C D(\mathrm{r}=-0.244 ; \mathrm{P}<0.05)$, and LTF $(\mathrm{r}=-0.318$; $\mathrm{P}<0.01)$ while positive correlations were determined between SCC and TLR2 $(\mathrm{r}=0.400 ; \mathrm{P}<0.001), P T X 3$ $(r=0.475 ; P<0.001), N F-k B(0.412 ; P<0.001)$, MDA levels $(r=0.418 ; P<0.001)$. Once for all, MDA levels were positively correlated with COX-2 $(r=0.273 ; P<0.05), T L R 2(r=0.453 ; P<0.001), P T X 3(r=0.412 ; P<0.001), N F-$ $k B(r=0.349 ; P<0.01), N R F 2(r=0.580 ; P<0.001)$, and SCC $(r=0.438 ; P<0.001)$.

\section{Discussion}

Somatic cell count is one of the most important parameter that gives an idea about mammary health and milk quality in ruminants. On the other hand, SCC of milk may be high even if the animal is healthy because of the secretion type of milk in goats ${ }^{1}$. Although high SCC in milk is not desired in general, Rainard et al. (2018) ${ }^{10}$ has stated that low SCC might also be a risk as it may increase susceptibility to mastitis. Colostrum, which is the first secretion of the mammary gland, contains quite high SCC compared to mature milk as well as its difference in composition ${ }^{5,11}$.

Similar to the study conducted in goats by Moreno-Indias et al. $(2012)^{5}$, SCC, which was initially about $5000 \times 10^{3} / \mathrm{mL}$ in colostrum, tended to gradually decrease during the transition to milk in this study. Sanches-Macias et al. (2014) ${ }^{6}$ reported that from the 0th day to the 4th day, SCC had decreased from approximately $9000 \times 10^{3} / \mathrm{mL}$ to $3000 \times 10^{3} / \mathrm{mL}$ levels, and after the 15 th day it had remained below $1000 \times 10^{3} / \mathrm{mL}$ as this studies results. High SCC in colostrum was thought to be physiological and the possible cause, as reported in other studies, might be due to the leaky tight junctions between mammary epithelial cells $s^{6,12}$. In addition, breed type of goat was thought to be an important factor for differences in terms of SCC during transition colostrum to mature milk. While pH of samples was lower on 0th day, it had gradually increased during transition similar to other studies ${ }^{13-15}$. It was reported that high $\mathrm{pH}$ could prevent bacterial contamination ${ }^{6}$. It was possible to evaluate this situation as one of the physiological self-protection mechanisms of the mammary gland during the transition period.

In milk transition period, milk composition and properties change in ruminants ${ }^{7,16}$. While higher fat percentages have continued until 7th day, lactose has found highest on 0th day dramatically decreased on 4th day and stayed stable. The possible reason why the initial sample lactose content is higher that 
lactose is a source of energy that may be digested faster than fat and required for newborn ${ }^{5}$. While most of the milk quality parameter has dramatically decreased during transition, freezing point and electrical conductivity has increased since 4th day of lactation. Expectative reason of increases on these parameters are decreased percentages of parameters such as fat, protein, FFDM of secretion in addition to other compounds as minerals. Also, it has been reported that genetic background of breeds affected the composition of colostrum and milk in goats ${ }^{7}$.

MDA is primary biomarker for determination the lipid peroxidation and oxidative stress in tissues. Moreover, it has been reported that lactation period strongly related with milk MDA levels and it has higher values in early lactation stage ${ }^{17}$. While significantly higher values have found in colostrum, MDA has dramatically decreased with the continuation of lactation. In a study, it has been reported that composition and yield of milk is significantly correlated with MDA levels in cow milk ${ }^{17}$. According to correlation results in our study, high SCC has also associated with increased MDA levels in mammary secretion. Although milk MDA levels are understandably dependent on milk composition, more exploration at the molecular levels is needed to elucidate the mechanism of MDA in colostrum and milk.

There is a limited number of study about fatty acid profile of colostrum and transition milk in goats ${ }^{18,19}$. It is essential to explore the milk fatty acid profile at different lactation stages to achieve the optimal benefits from milk. Goat milk is richer from short-chain fatty acids. It has been determined that shortchain fatty acids responsible for the odour index in milk has tended to increase during the transition to mature milk. Beside short-chain fatty acids, medium-chain fatty acids have also increased during transition. It has reported that medium-chain fatty acids (C8:0, C10:0 and C12:0) in milk have antimicrobial effects ${ }^{20}$. Goat kids are susceptible to infections and therefore medium-chain fatty acids in secretion may have increased for the protective effects on young goats ${ }^{18}$. While short and medium-chain fatty acids and some of the long-chain fatty acids have gradually increased in the transition from colostrum to milk, some of the long-chain fatty acids have stayed stable from 0th to 28th day. It has thought that the likely cause of these results is unchanged ration ingredients of animals. Just because of it is known that composition of ration has major effect on the fatty acid profile of goat milk ${ }^{21}$.

To date, effects of many genes related to fatty acid synthesis have been investigated in mammals. Milk fatty acids have been used as biomarkers in the diagnosis of feed efficiency, lipid mobilization, and some of the specific disorders ${ }^{22}$. PUFA, odour index, $n 6$, and $n 3$ have increased with the continuation of lactation, while $\mathrm{n} 6 / \mathrm{n} 3$ ratio has decreased. Hence, milk has become better quality with the transition period $^{23}$. Compared to early lactation, percentage of PUFA has increased in 28 th day. It has reported to decrease towards the end of the lactation in different goat breeds ${ }^{24}$. However, it has increased in the transition processes from colostrum to mature milk in this study. Although it has known that nutrition has important effects on milk fatty acid profile, studies show that the lactation period is another major point on this parameter ${ }^{25,26}$. While there have been controversial reports about fatty acid profile of milk in different lactation stages 24,27 , it has been showed up fatty acid profile of goat milk is one of the most variable components among the lactation period, together with milk yield and composition ${ }^{26}$. 
The molecular regulation of lipid metabolism remains largely unknown in ruminants. Fatty acid biosynthesis is an intriguingly complex biological process and $F A S N, S C D$, and $A C A C A$ are largely effective genes in lipid biosynthesis. $F A S N$, one of the highly expressed gene in goat colostrum, has been reported required for the maintenance of lactation ${ }^{25,28}$. Therewithal, FASN has mostly responsible to synthesis of short and medium-chain fatty acids together with $A C A C A^{25}$. It has been reported that inhibition of FASN led to reduce of medium-chain fatty acids and downregulation of ACACA in mammary gland of goat ${ }^{29}$. In addition, $F A S N$ in goat mammary gland might synthesize three fatty acid forms (short, medium and long-chain fatty acids) ${ }^{29}$. Herewith in this study, the expression level of FASN and ACACA has tended to fluctuated, although they have increased during the transition period. On the other hand, $S C D$ has showed similar expression levels. SCD is major regulator of MUFA synthesis in the mammary gland and MUFA levels has also stayed stable in all sampled days ${ }^{30}$. It has been reported that $F A S N$, $A C A C A$, and $S C D$ had regulated together from pregnancy to end of the lactation in bovine mammary gland $^{31}$. The positive correlations found between these genes have shown that they interact in the formation of the fatty acid profile of goat milk. It has been reported in recent studies, FASN, SCD and $A C A C A$ genes might be candidate genes for qualified animal product from the point of fatty acid profile ${ }^{30,32-34}$. While some researches have studied on expression patterns of FASN, SCD and ACACA genes in goats $28,30,34$, to our knowledge there is no report about the activities of these genes in colostrum and transitional milk somatic cells of goats. It has clearly understood that despite the differences in upregulation levels, regulation of fatty acid synthesis in goat colostrum and early milk requires coordinately expression of mentioned genes.

With the beginning of lactation, antioxidant and immunological mechanisms have showed abnormal regulation in mammary gland. Antioxidant status of colostrum is important for maternal physiology and offspring health ${ }^{35}$. COX-2 and NRF2 are the most related genes with the oxidative status of tissues and biological liquids and have tended to be upregulation in response to immunological activity 36,37 . It has been reported that $N R F 2$ increases by triggering $T L R 2$ in leukocytes and oxidative stress may decrease by overexpressing $T L R 2$ in goats ${ }^{38}$. In transition period, both COX-2 and NRF2 genes have showed significant downregulation with the similar expression patterns of $T L R 2$ and $N F-k B$ in milk somatic cells. In inflammation status, oxidative stress initiates the inflammatory response by activating $N F-k B$ and increases the expression levels of target genes such as $C O X-2$. It has been reported that response to oxidative stress is formed by cross-interaction between NRF2 and NF-kB ${ }^{39}$. Moreover, $P T X 3$ gene has also shown downregulation with continuation of lactation. Hence, expected correlations have obtained between mentioned genes expression levels in goat milk somatic cells.

Together with the rapid decrease number of somatic cells, PTX3 downregulated more than 3 folds on the 14th and 28th days. PTX3, which expression level has decreased with the transition from colostrum to mature milk, is thought to be regulated for both kid and maternal health. PTX3 has known to be a gene regulated by the molecular mechanisms of innate resistance to respond to infectious agents ${ }^{40,41}$. There has been limited knowledge about the activity and expression patterns of PTX3 in healthy goats, while 
one of the most expression of PTX3 has been reported is mammary gland ${ }^{42}$. It has been stated that PTX3 gene might be upregulated by inflammation in mammary tissue and its activity might be used an early marker of mastitis ${ }^{42,43}$. It has advocated that whether there is a correlation between PTX3 and SCC should be investigated in goat milk ${ }^{42}$. The results obtained from our study show that in addition to relations with the oxidative and inflammatory genes such as $T L R 2$ and $N F-k B$, there is crucial correlation between PTX3 and SCC in early lactation of goats.

LTF has showed similar expression patterns during the transition. While negative correlation has been found between $L T F$ and SCC as expected, it has positively correlated with FASN, SCD, and ACACA. In addition to the antimicrobial activities of medium-length fatty acids synthesized by the activities of FASN, $S C D$ and $A C A C A, L T F$ has also antimicrobial activity in mammary gland ${ }^{44}$. However, what is known about the relation between fatty acid synthesis and $L T F$ activity is quiet limited. Therefore, more research is needed on direct and indirect relations between $L T F$ and fatty acid biosynthesis in mammary gland.

Indicator of oxidative stress and cytokines have known transferred from mother with colostrum and milk, may affecting the health of offspring ${ }^{45}$. On a study it has reported that it is appropriate to weaning of lambs at 28 days $^{46}$. In addition to health of kids and goats, transition and mature milk should be investigated at the molecular levels for milk quality parameters.

In conclusion, variable interactions between genes have showed that the regulation of goat milk are intriguingly reorganized in transition process. To our knowledge this is the first study to deeply explore the changes at the molecular levels of mammary secretion of goats from birth to 28th day of lactation. In addition, the additive effects of studied genes have significant roles on properties of colostrum, transition and mature milk in goats. To elucidate the underlying molecular mechanism of the goat mammary secretion, more comprehensive study is needed in this field.

\section{Methods}

\section{Ethical statement}

All methods on animals were reviewed and approved by the Animal Experiments Local Ethics Committees of Hatay Mustafa Kemal University. The procedures strictly complied with the "Regulation on the Studying Procedures and Principles of Animal Experiments of Ethics Committees" of Ministry of Agriculture and Forestry (2014, Republic of Turkey). In addition, the approval of the farm owner was obtained for the study.

\section{Materials, design of the study, samples collection and measuring parameters}

This research was conducted with Damascus goats aged 3-4 years in a private goat enterprise located at $36^{\circ} 21^{\prime} 52.6^{\prime \prime} \mathrm{N}$ and $36^{\circ} 15^{\prime} 14.6^{\prime \prime} \mathrm{E}$ at an altitude of $82 \mathrm{~m}$ above sea level in the Eastern Mediterranean region of Turkey (Hatay Province). Healthy 24 head goats were randomly selected from 200 heads flock. Goats consumed $1.2 \mathrm{~kg} /$ head concentrated feed and $1.0 \mathrm{~kg} /$ head wheat straw on a daily basis (Table 2). 
Following parturitions, approximately $150 \mathrm{~mL}$ colostrum or morning milk samples were collected to nuclease free falcon tubes on the $0^{\text {th }}, 4^{\text {th }}, 7^{\text {th }}, 14^{\text {th }}$, and $28^{\text {th }}$ days. Prior to sampling, udders and teats of goats were cleaned with sterile cotton gauzes.

Table 2. Chemical and physical composition of concentrate feeds; *: Per $1.5 \mathrm{~kg}$ premix contains 15000 000 IU Vit A, 3000000 IU Vit D3, 50000 IU Vit E, 50 g manganese, $50 \mathrm{~g}$ ferrous, $50 \mathrm{~g}$ zinc, $10 \mathrm{~g}$ copper, 0.8 $\mathrm{g}$ iodine, $0.2 \mathrm{~g}$ cobalt, $0.3 \mathrm{~g}$ selenium.

\begin{tabular}{|ll|}
\hline Items contents & Proportions (\%) \\
\hline Wheat & 19.50 \\
Maize Barn & 20.60 \\
Corn & 18.50 \\
Sunflower meal & 15.50 \\
Cottonseed meal & 10.00 \\
Barley & 7.50 \\
Wheat Barn & 2.30 \\
Molasses & 5.00 \\
Marble powdered (\%38 Ca ${ }^{++)}$ & 0.30 \\
NaCl & 0.70 \\
Premix* & 0.10 \\
Total & 100.00 \\
\hline Dry Matter & 88.91 \\
Crude ash & 5.96 \\
Ether extract & 2.58 \\
Crude protein & 16.51 \\
\hline Total Metabolic Energy (kcal/kg) & 2649.28 \\
\hline
\end{tabular}

Samples were transported to the laboratory at $4{ }^{\circ} \mathrm{C}$ in $30 \mathrm{~min}$. Approximately quarter of each sample was used for determination of SCC (Lactoscan SCC 6010, BULGARIA) and pH (Hanna pH meter, HI83141, USA) values. Fat, FFDM, protein, lactose, freezing point, and electrical conductivity parameters were measured with milk analyzer (Milkotester Master Classic LM2-P1, BULGARIA). In addition, the levels of MDA were determined with UV-Spectrophotometer at $532 \mathrm{~nm}$ wavelength ${ }^{47}$. All parameters were measured within 2 hours of milking in two replicates and mean values were recorded. 


\section{Cream layer and somatic cells collection}

Approximately $50 \mathrm{~mL}$ of milk sample were centrifuged at $+4{ }^{\circ} \mathrm{C}$ at $1800 \mathrm{xg}$ for $15 \mathrm{~min}$ (for colostrum samples, $25 \mathrm{ml}$ of colostrum was completed to $50 \mathrm{ml}$ with the same volume of PBS and homogenized). Thereafter the samples were kept for about $15 \mathrm{~min}$ at $-20^{\circ} \mathrm{C}$. After the cream layer was collected and stored $-20^{\circ} \mathrm{C}$ for fatty acid analyzes, the supernatant phase was poured out and PBS was added to the bottom cell pellet and homogenized. Centrifugation was repeated at $+4{ }^{\circ} \mathrm{C}$ at $1800 \mathrm{xg}$ for $15 \mathrm{~min}$. Supernatant phases of samples were discarded and approximately $1 \mathrm{~mL}$ TRIzol Reagent (Sigma-Aldrich, USA) was added to cell pellets and homogenized by pipetting. Following the homogenization, samples were stored $-86^{\circ} \mathrm{C}$ until RNA isolation.

\section{Fatty acid analyzes}

For fatty acid profiles of samples, $500 \mu \mathrm{L}$ cream was used from each sample. Samples were homogenized with $2 \mathrm{~mL}$ of $2 \mathrm{~N}$ methanolic $\mathrm{KOH}$ for $4 \mathrm{~min}$ at room temperature. Then $4 \mathrm{ml}$ of $\mathrm{n}$-Heptane (Merck, USA) was added to samples and kept for 2 minutes at room temperature. Following the centrifugation at $200 \mathrm{xg}$ for $5 \mathrm{~min}$, the aqueous phases of samples containing methyl esters were transferred to $1.5 \mathrm{~mL}$ vials. Fatty acids of samples were determined by Gas Chromatography equipped with flame ionization detector (Shimadzu GC-2025, Japan), auto-injector (Shimadzu AOC-20i, JAPAN) and Restek Rt-2560 column (100 m length, $0.25 \mathrm{~mm}$ ID x $0.20 \mu \mathrm{m}$ ). Temperatures of injector and detector were both kept at $250{ }^{\circ} \mathrm{C}$. Hydrogen was used as carrier gas and the gas flow was $1.20 \mathrm{~mL} / \mathrm{min}$. Injection mode was split mode with split ratio of 1:50 and total injection volume was $1 \mu \mathrm{L}$. Injector was rinsed with $\mathrm{n}$-Heptane, three times pre-run and six times post-run. Temperature gradient program was used. The initial oven temperature was $100{ }^{\circ} \mathrm{C}$ (hold for $2 \mathrm{~min}$ ) and it was then increased by $4{ }^{\circ} \mathrm{C} / \mathrm{min}$ until $250^{\circ} \mathrm{C}$ (hold for $15 \mathrm{~min}$ ). The run was $54.50 \mathrm{~min}$. For the verification of fatty acids, the determined sample peaks retention times were compared with that of internal standard (FAME Mix, Restek, USA).

\section{Total RNA isolation, genomic DNA digestion and cDNA synthesis}

Total RNA was isolated from the somatic cells by standard TRIzol method ${ }^{48}$. According to protocol, 250 $\mu \mathrm{L}$ chloroform was added to cell suspensions homogenized in TRIzol Reagent and gently mixed. After waiting $10 \mathrm{~min}$ at room temperature, samples were centrifuged at $+4^{\circ} \mathrm{C}$ at $12000 \mathrm{xg}$ for $15 \mathrm{~min}$. Aqua phases of samples were collected to new sterile-nuclease free centrifuge tubes and isopropyl alcohol was added as much as half of the TRIzol Reagent added in the samples. The samples were briefly mixed and stored up at room temperature for $10 \mathrm{~min}$. For precipitation RNA, samples were centrifuged at $4{ }^{\circ} \mathrm{C}$ at $12000 \mathrm{xg}$ for $10 \mathrm{~min}$. Supernatants of samples were discarded following the centrifuge and $1 \mathrm{~mL} 70 \%$ ethyl alcohol was added to sample. The samples added $70 \%$ ethyl alcohol were centrifuged at $4^{\circ} \mathrm{C}$ at $7500 \mathrm{xg}$ for $5 \mathrm{~min}$. This step was performed twice. Samples were centrifuged for the last time with $1 \mathrm{~mL}$ $96 \%$ ethyl alcohol at similar conditions. Finally, RNA pellets were kept at room temperature for 10 min then dissolved with 30-100 $\mu \mathrm{L}$ nuclease-free water. Purity $\left(\mathrm{A}_{260 / 280}\right)$ and concentration of RNA were controlled by nucleic acid spectrophotometer (Merinton SMA-1000 UV Spectrophotometer, CHINA). In 
addition, quality of RNA was checked by evaluated $28 \mathrm{~S}$ and $18 \mathrm{~S}$ rRNA bands with $1 \%$ agarose gel electrophoresis (100 $\mathrm{V}$ and $25 \mathrm{~min}$ ).

DNA digestion protocol was carried out to samples for eliminating possible genomic DNA contamination (DNase I, RNase free, Thermo Fisher Scientific, USA). Total RNA was then converted to cDNA with using cDNA synthesis kit (RevertAid First Strand cDNA Synthesis Kit, Thermo Fisher Scientific, USA). Protocol of thermal cycler (Bio-Rad T100, USA) was as follows: Samples were kept at $25^{\circ} \mathrm{C}$ for $10 \mathrm{~min}$, subsequently at $37^{\circ} \mathrm{C}$ for $120 \mathrm{~min}$, and then at $85^{\circ} \mathrm{C}$ for $5 \mathrm{~min}$. Following the reaction, sample were completed to 150 $\mu \mathrm{L}$ and kept at $-20^{\circ} \mathrm{C}$ until gene expression analyzes.

\section{Real-Time qPCR application}

Amplifications of FASN, SCD, ACACA, COX-2, NRF2, TLR2, NF-kB, LTF, and PTX3 were performed using 10 $\mu \mathrm{L}$ of each cDNA samples in RT-qPCR (Bio-Rad CFX-96 Touch Real time PCR, USA). SYBR Green I dye containing kit (Power SYBR Green PCR Master, Thermo Fisher Scientific, USA) was used for amplification and each sample was studied as duplicated. The reaction was arranged $10 \mathrm{~min}$ at $95^{\circ} \mathrm{C}$, followed by 15 sec at $95^{\circ} \mathrm{C}, 60 \mathrm{sec}$ at $60^{\circ} \mathrm{C}$, and 40 cycles in RT-qPCR. On the other hand, ACTB and G6PD reference genes were used as internal control. Forward and reverse sequences of primers were shown in Table 3 .

Table 3. Forward and reverse sequences of primers amplified genes 


\begin{tabular}{|c|c|c|c|}
\hline Genes & Forward and Reverse Sequences of Primers & Product Length & Reference \\
\hline \multirow[t]{2}{*}{ FASN } & F: 5'-GCACACAATATGGACCCCCA-3' & 183 & Designed by authors \\
\hline & R: 5'-CATGCTGTAGCCTACGAGGG-3' & & \\
\hline \multirow[t]{2}{*}{$S C D$} & F: 5'-ATCGCCCTTACGACAAGACC-3' & 186 & Designed by authors \\
\hline & R: 5'-CATAAGCCAGACCGATGGCA-3' & & \\
\hline \multirow[t]{2}{*}{ ACACA } & F: 5'-GCCTGCCCGAGTTTTGAGTG-3' & 105 & Designed by authors \\
\hline & R: 5'-CGCACTCTGGAGCGGATAAA-3' & & \\
\hline \multirow[t]{2}{*}{$\operatorname{coX}-2$} & F: 5'-GTAGGCCAGGAGGTCTTTGG-3' & 142 & Designed by authors \\
\hline & R: 5'- GCCTGCTTGTCTGGAACAAC-3' & & \\
\hline \multirow[t]{2}{*}{ NRF2 } & F: 5'-CTGTTCTCTGCTGTCAAGGG-3' & 222 & Designed by authors \\
\hline & R: 5'-AACTCGCCGGTCTCTTCATC-3' & & \\
\hline \multirow[t]{2}{*}{$T L R 2$} & F: 5'-TGCTGTGCCCTCTTCCTGTT-3' & 260 & 38 \\
\hline & R: 5'-GGGACGAAGTCTCGCTTATGAA-3' & & \\
\hline \multirow[t]{2}{*}{$N F-k B$} & F: 5'-TGGGGATACTGAACAACGCC-3' & 115 & Designed by authors \\
\hline & R: 5'-ATCTGTCTCAGGGCCTCCAT-3' & & \\
\hline \multirow[t]{2}{*}{ LTF } & F: 5'-CAAGTGTGTGCCCAACTCTA-3' & 105 & 49 \\
\hline & R: 5'-GCTCTCTCCATTCGTGTTCTC-3' & & \\
\hline \multirow[t]{2}{*}{ PTX3 } & F: 5'-CCTGCATTTGGGTCAAAGCC-3' & 186 & Designed by authors \\
\hline & R: AATCACAGCATCAGCGACCA-3' & & \\
\hline \multirow[t]{2}{*}{ ACTB } & F: 5'-TGGATCGAGCATCCCCAAAG-3' & 169 & Designed by authors \\
\hline & R: 5'-ACTGGCCCCTTCTCCTTAGA-3' & & \\
\hline \multirow[t]{2}{*}{ G6PD } & F: 5'-TGACCTATGGCAACCGATACAA-3' & 76 & 50 \\
\hline & F: 5'-CCGCAAAAGACATCCAGGAT-3' & & \\
\hline
\end{tabular}

\section{Statistical analysis}

Descriptive statistics for each variable were calculated and presented as "Mean \pm Standard Error of Mean". The Pearson correlation coefficient was used to determine the correlation between gene expression levels, somatic cell count and MDA levels. To determine the effect of time of sampling on milk quality and milk fatty acid parameters, linear mixed model was used. The following model with repeated measures design: $Y_{i j k}=\mu+T_{j}+e_{i j k}$. Where, $Y_{i j k}$, dependent variable; $\mu$, overall mean; $T_{j}$, effect of time of 
sampling ( $\mathrm{j}=$ Day of parturition, after parturition 4, 7, 14 and $28 \mathrm{~d}$ ) and $\mathrm{e}_{\mathrm{ijk}}$, residual error. Animals were assessed as a random effect, while the time of sampling was assessed as fixed effect. When a significant difference was revealed, any significant terms was compared by simple effect analysis with Bonferroni adjustment. $\mathrm{P}<0.05$ was considered as significant in all analyses. All data were analyzed using IBM SPSS Statistics software (Version 23.0) ${ }^{51}$.

Expression levels of genes were calculated by the $2^{-\Delta \Delta C t}$ method and geometric mean of reference genes $\mathrm{Ct}$ values was used for gene expression analyzes ${ }^{52}$. The results were determined with comparing to $0^{\text {th }}$ day and presented as fold changes.

\section{Declarations}

\section{Acknowledgements}

This study was supported by the Scientific and Technological Research Council of Turkey (TUBITAK) with the 1190716 project number.

\section{Author Contributions}

A.Y. and H.Ö. conceived and investigated the study. A.Y. supervised of the study. H.Ö. and B.Ç. collected samples, and performed RNA isolation and gene expression applications. B.Ç. and S.Y. determined the milk parameters. B.Ç. and I..K. determined the fatty acid profile of samples. A.Y., H.Ö. and U.K. analyzed the results. A.Y. and H.Ö. wrote the manuscript. All authors read and approved the final manuscript.

Competing Interests: The authors declare no competing interests.

\section{References}

1. Clark, S. \& García, M. B. M. A 100-year review: Advances in goat milk research. J. Dairy Sci. 100, 10026-10044 (2017).

2. Yurchenko, S. et al. Fatty acid profile of milk from Saanen and Swedish Landrace goats. Food Chem. 254, 326-332 (2018).

3. Skapetas, B. \& Bampidis, V. Goat production in the World: present situation and trends. Livest Res Rural Dev 28, 200 (2016).

4. Novotná, K. et al. Impact of concentrate level and stage of lactation on fatty acid composition in goat milk. Sci. Agric. Bohem. 50, 171-175 (2019).

5. Moreno-Indias, I. et al. Chemical composition and immune status of dairy goat colostrum fractions during the first $10 \mathrm{~h}$ after partum. Small Rumin. Res. 103, 220-224 (2012).

6. Sánchez-Macías, D., Moreno-Indias, I., Castro, N., Morales-Delanuez, A. \& Argüello, A. From goat colostrum to milk: Physical, chemical, and immune evolution from partum to 90 days postpartum. J. Dairy Sci. 97, 10-16 (2014). 
7. Rachman, A. B., Maheswari, R. R. A. \& Bachroem, M. S. Composition and isolation of lactoferrin from colostrum and milk of various goat breeds. Procedia Food Sci. 3, 200-210 (2015).

8. Chilliard, Y. et al. Effects of diet and physiological factors on milk fat synthesis, milk fat composition and lipolysis in the goat: A short review. Small Rumin. Res. 122, 31-37 (2014).

9. Marziali, S. et al. Effect of early lactation stage on goat colostrum: Assessment of lipid and oligosaccharide compounds. Int. dairy J. 77, 65-72 (2018).

10. Rainard, P. \& Foucras, G. A critical appraisal of probiotics for mastitis control. Front. Vet. Sci. 5, 251 (2018).

11. Csanádi, J., Fenyvessy, J. \& Bohata, S. Somatic cell count of milk from different goat breeds. Acta Univ. Sapientiae, Aliment. 8, 45-54 (2015).

12. Nguyen, D.-A. D. \& Neville, M. C. Tight junction regulation in the mammary gland. J. Mammary Gland Biol. Neoplasia 3, 233-246 (1998).

13. Argüello, A., Castro, N., Alvarez, S. \& Capote, J. Effects of the number of lactations and litter size on chemical composition and physical characteristics of goat colostrum. Small Rumin. Res. 64, 53-59 (2006).

14. Agnihotri, M. K. \& Rajkumar, V. Effect of breed, parity and stage of lactation on milk composition of western region goats of India. Int. J. Dairy Sci. 2, 172-177 (2007).

15. Addass, P. A., Tizhe, M. A., Midau, A., Alheri, P. A. \& Yahya, M. M. Effect of genotype, stage of lactation, season and parity on milk composition of goat in Mubi, Adamawa State, Nigeria. Ann. Biol. Res. 4, 248-252 (2013).

16. Arain, H. H., Khaskheli, M., Arain, M. A., Soomro, A. H. \& Nizamani, A. H. Heat stability and quality characteristics of postpartum buffalo milk. Pak J Nutr 7, 303-307 (2008).

17. Kapusta, A., Kuczyńska, B. \& Puppel, K. Relationship between the degree of antioxidant protection and the level of malondialdehyde in high-performance Polish Holstein-Friesian cows in peak of lactation. PLoS One 13, e0193512 (2018).

18. Marounek, M., Pavlata, L., Mišurová, L., Volek, Z. \& Dvořák, R. Changes in the composition of goat colostrum and milk fatty acids during the first month of lactation. Czech J Anim Sci 57, 28-33 (2012).

19. Yang, X., Chen, J. \& Zhang, F. Research on the chemical composition of Saanen goat colostrum. Int. J. dairy Technol. 62, 500-504 (2009).

20. Desbois, A. P. \& Smith, V. J. Antibacterial free fatty acids: activities, mechanisms of action and biotechnological potential. Appl. Microbiol. Biotechnol. 85, 1629-1642 (2010).

21. Chilliard, Y. \& Ferlay, A. Dietary lipids and forages interactions on cow and goat milk fatty acid composition and sensory properties. Reprod. Nutr. Dev. 44, 467-492 (2004).

22. Cecchinato, A. et al. Genetic and genomic analyses of latent variables related to the milk fatty acid profile, milk composition, and udder health in dairy cattle. J. Dairy Sci. 102, 5254-5265 (2019). 
23. Lopez, A., Vasconi, M., Moretti, V. M. \& Bellagamba, F. Fatty acid profile in goat milk from high-and low-input conventional and organic systems. Animals 9, 452 (2019).

24. Currò, S. et al. Effects of Breed and Stage of Lactation on Milk Fatty Acid Composition of Italian Goat Breeds. Animals 9, 764 (2019).

25. Crisà, A., Ferrè, F., Chillemi, G. \& Moioli, B. RNA-Sequencing for profiling goat milk transcriptome in colostrum and mature milk. BMC Vet. Res. 12, 264 (2016).

26. Zhang, Y., Zheng, Z., Liu, C. \& Liu, Y. Lipid Profiling and Microstructure Characteristics of Goat Milk Fat from Different Stages of Lactation. J. Agric. Food Chem. 68, 7204-7213 (2020).

27. Kuchtík, J. et al. Changes in physico-chemical characteristics, somatic cell count and fatty acid profile of Brown Short-haired goat milk during lactation. Anim. Sci. Pap. Reports 33, 71-83 (2015).

28. Suburu, J. et al. Fatty acid synthase is required for mammary gland development and milk production during lactation. Am. J. Physiol. Metab. 306, E1132-E1143 (2014).

29. Zhu, J. J. et al. Inhibition of FASN reduces the synthesis of medium-chain fatty acids in goat mammary gland. Animal 8, 1469-1478 (2014).

30. Tudisco, R. et al. Influence of pasture on goat milk fatty acids and Stearoyl-CoA desaturase expression in milk somatic cells. Small Rumin. Res. 122, 38-43 (2014).

31. Bionaz, M. \& Loor, J. J. Gene networks driving bovine milk fat synthesis during the lactation cycle. BMC Genomics 9, 366 (2008).

32. Piórkowska, K. et al. Evaluation of SCD, ACACA and FASN Mutations: Effects on Pork Quality and Other Production Traits in Pigs Selected Based on RNA-Seq Results. Animals 10, 123 (2020).

33. Yang, C. et al. The response of gene expression associated with lipid metabolism, fat deposition and fatty acid profile in the longissimus dorsi muscle of Gannan yaks to different energy levels of diets. PLoS One 12, e0187604 (2017).

34. Bernard, L. et al. Effect of sunflower-seed oil or linseed oil on milk fatty acid secretion and lipogenic gene expression in goats fed hay-based diets. J. Dairy Res. 76, 241-248 (2009).

35. Moretti, D. B., Santos, C. B., Alencar, S. M. \& Machado-Neto, R. Colostrum from primiparous Holstein cows shows higher antioxidant activity than colostrum of multiparous ones. J. Dairy Res. 87, 356359 (2020).

36. Pfaffl, M. W., Wittmann, S. L., Meyer, H. H. D. \& Bruckmaier, R. M. Gene expression of immunologically important factors in blood cells, milk cells, and mammary tissue of cows. J. Dairy Sci. 86, 538-545 (2003).

37. Özkan, H. \& Yakan, A. The Relationship Between Milk Fatty Acid Profile and Expression Levels of SCD, FASN and SREBPF1 Genes in Damascus Dairy Goats. Kocatepe Vet. Derg. 13, 1 (2020).

38. Deng, S. et al. Over-expression of Toll-like receptor 2 up-regulates heme oxygenase-1 expression and decreases oxidative injury in dairy goats. J. Anim. Sci. Biotechnol. 8, 3 (2017).

39. Han, L. et al. Methionine supply alters mammary gland antioxidant gene networks via phosphorylation of nuclear factor erythroid 2-like 2 (NFE2L2) protein in dairy cows during the 
periparturient period. J. Dairy Sci. 101, 8505-8512 (2018).

40. Lutzow, Y. C. S. et al. Identification of immune genes and proteins involved in the response of bovine mammary tissue to Staphylococcus aureus infection. BMC Vet. Res. 4, 18 (2008).

41. Cremonesi, P. et al. Response of the goat mammary gland to infection with Staphylococcus aureus revealed by gene expression profiling in milk somatic and white blood cells. BMC Genomics 13, 540 (2012).

42. Filipe, J. et al. Pentraxin 3 is up-regulated in epithelial mammary cells during Staphylococcus aureus intra-mammary infection in goat. Comp. Immunol. Microbiol. Infect. Dis. 59, 8-16 (2018).

43. Brenaut, P. et al. Contribution of mammary epithelial cells to the immune response during early stages of a bacterial infection to Staphylococcus aureus. Vet. Res. 45, 16 (2014).

44. Ward, P. P., Paz, E. \& Conneely, O. M. Lactoferrin. Cell. Mol. life Sci. 62, 2540 (2005).

45. Wang, X. et al. Temporal proteomic analysis reveals continuous impairment of intestinal development in neonatal piglets with intrauterine growth restriction. J. Proteome Res. 9, 924-935 (2010).

46. Zhang, X., Liu, X., Li, F. \& Yue, X. The Differential Composition of Whey Proteomes in Hu Sheep Colostrum and Milk during Different Lactation Periods. Animals 10, 1784 (2020).

47. Esterbauer, H. \& Cheeseman, K. H. [42] Determination of aldehydic lipid peroxidation products: malonaldehyde and 4-hydroxynonenal. in Methods in enzymology vol. 186 407-421 (Elsevier, 1990).

48. Rio, D. C., Ares, M., Hannon, G. J. \& Nilsen, T. W. Purification of RNA using TRIzol (TRI reagent). Cold Spring Harb. Protoc. 2010, pdb-prot5439 (2010).

49. Yakan, A., Özkan, H., Şakar, A. E., Ünal, N. \& Özbeyaz, C. Gene expression levels in some candidate genes for mastitis resistance, milk yield, and milk quality of goats reared under different feeding systems. Turkish J. Vet. Anim. Sci. 42, 18-28 (2018).

50. Garcia-Crespo, D., Juste, R. A. \& Hurtado, A. Selection of ovine housekeeping genes for normalisation by real-time RT-PCR; analysis of PrPgene expression and genetic susceptibility to scrapie. BMC Vet. Res. 1, 3 (2005).

51. SPSS, I. B. M. Statistics for Windows [Computer Program]. Version 23.0. (2015).

52. Livak, K. J. \& Schmittgen, T. D. Analysis of relative gene expression data using real-time quantitative PCR and the $2-\Delta \Delta C T$ method. methods 25, 402-408 (2001).

\section{Figures}



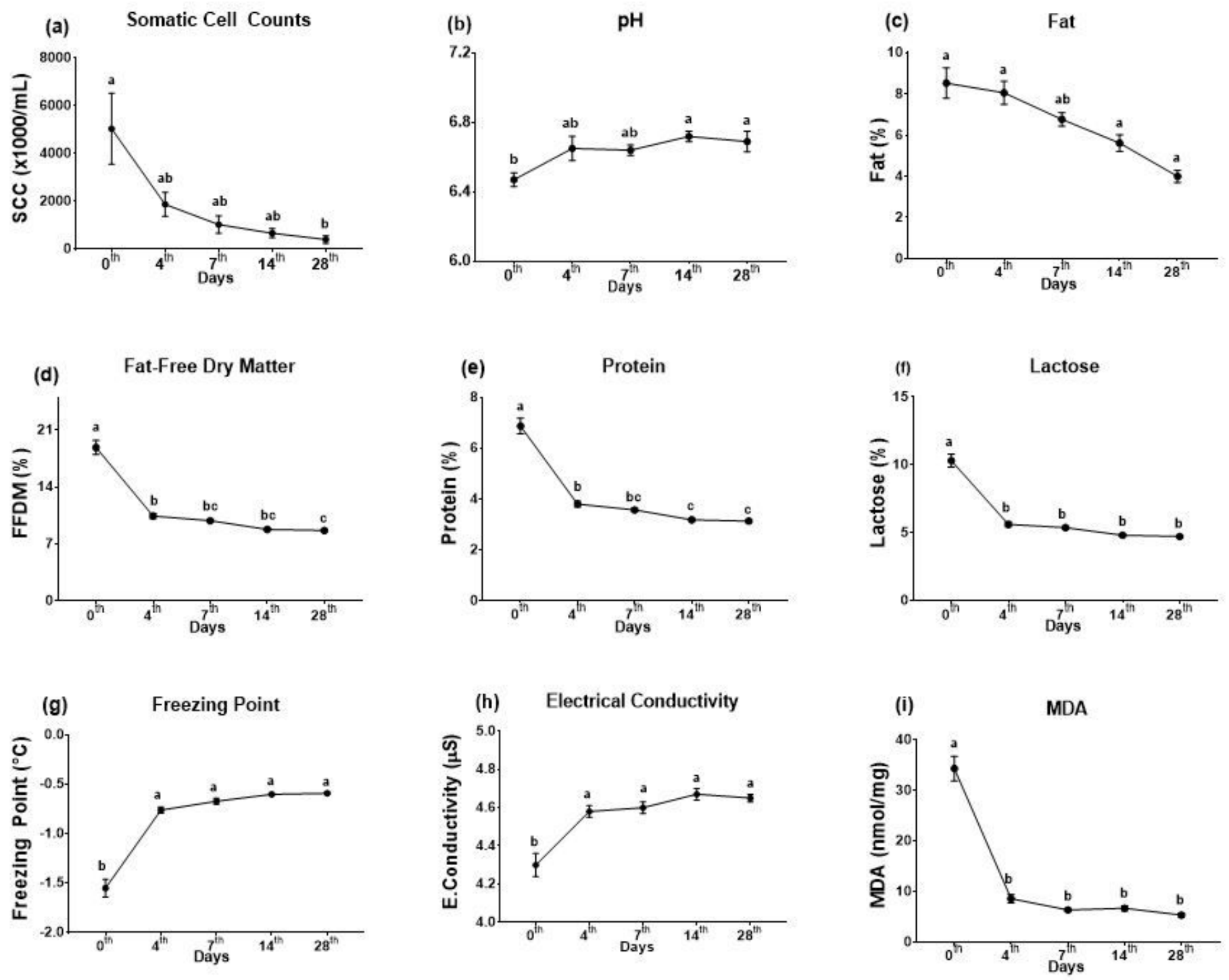

Figure 1

SCC, pH and compositional parameters on sampled days. (a) SCC, Somatic Cell Count, (b) pH values, (c) fat percentages, (d) Fat-Free Dry Matter percentages, (e) Protein percentages, (f) lactose percentages, (g) freezing point of samples, (h) electrical conductivity values, (i) Malondialdehyde levels of samples. 


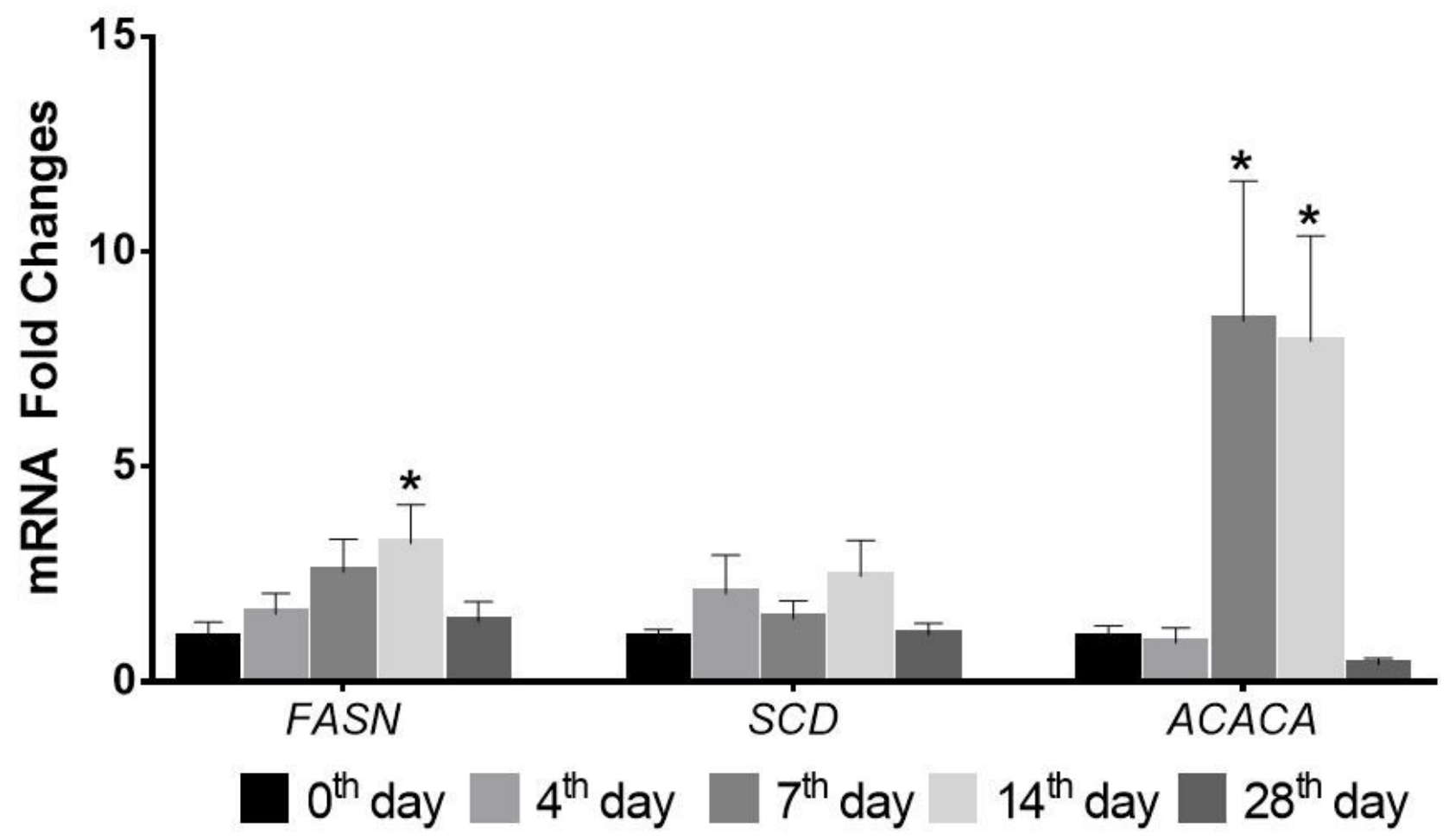

Figure 2

Expression levels of FASN, SCD, and ACACA genes in milk somatic cells, *: $P<0.05$

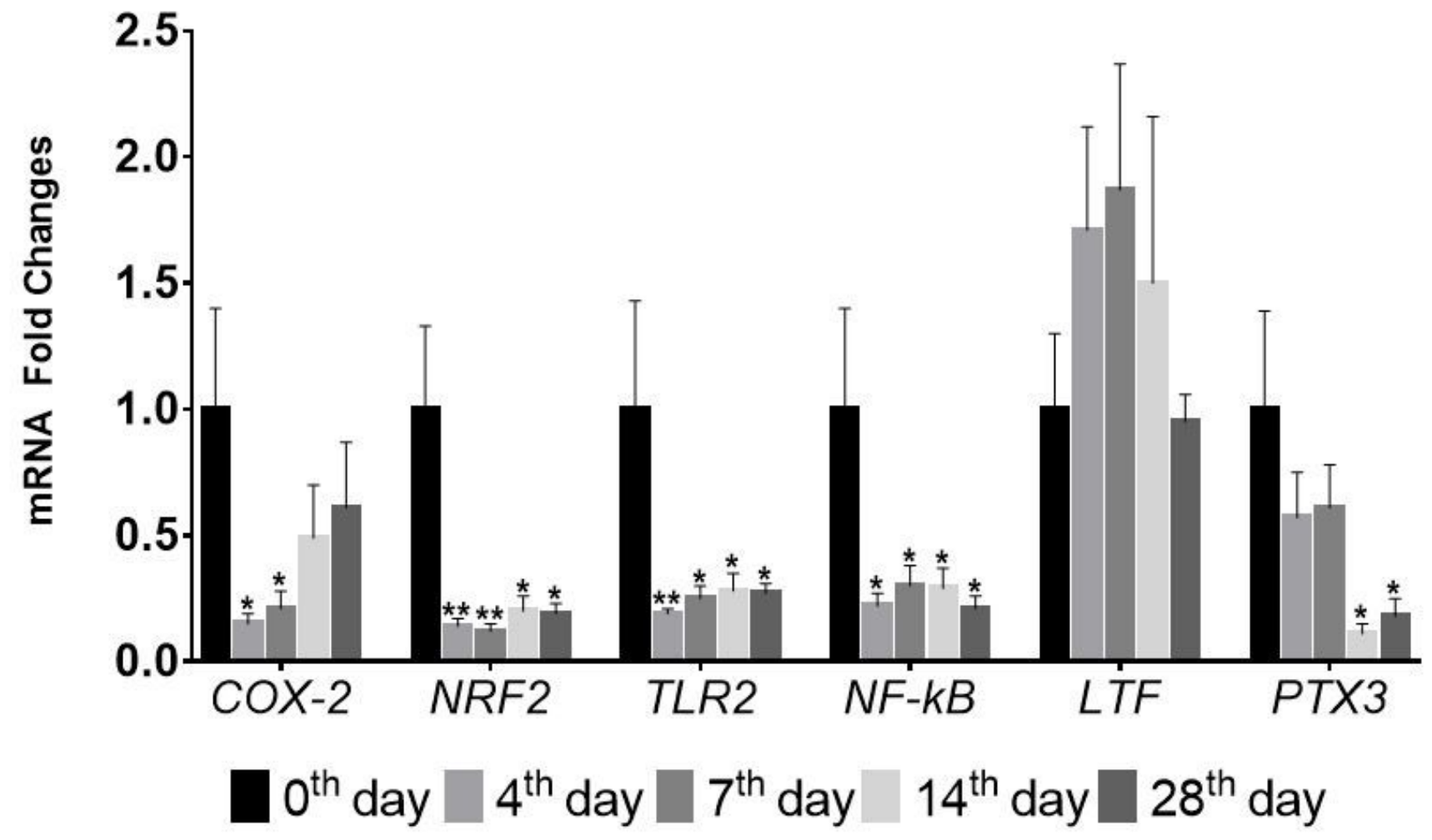

Figure 3 
Expression levels of COX-2, NRF2, TLR2, NF-kB, LTF, and PTX3 genes in milk somatic cells, *: $P<0.05$, **: $\mathrm{P}<0.01$ 